\title{
PIRACTWO INTERNETOWE A WOLNOŚĆ SŁOWA I DOSTĘPU DO TREŚCI W INTERNECIE
}

\author{
Abstract \\ INTERNET PIRACY - LIMITATIONS ON THE FREEDOM OF SPEECH AND \\ ACCESS TO THE CONTENT ON THE INTERNET
}

Many young Internet users equate freedom of speech with the freedom to access content disseminated on the web - treating both concepts as synonyms. Internet piracy undoubtedly has serious consequences for the economy. It is the example of sophisticated methods of violating intellectual property rights. It causes financial losses in music, publishing and media sectors and film industry. Accurate assessment of the losses is difficult. A lot of web users support pirates, thus becoming a part of their profitable business. Prosecution of the subjects illegally distributing and storing pieces is sometimes extremely complicated. It is so due to difficulties in identifying perpetrators and jurisdictional problems. Digital technologies which occur on the internet are easily adopted before any adequate laws are introduced, and the existing copyright laws stem from the experience of the era of analog technology. Current lawmakers try to create norms and rules which would befit the constantly changing digital reality and they are still one step behind.

Key words: freedom of access to the Internet, freedom of speech, Internet piracy, intellectual property protection, the economic effect of piracy, EU legislation regarding online theft, estimating losses, fighting pirate practices

\section{Wstęp}

Związek internetowego piractwa - generującego ewidentne straty ekonomiczne w przemyśle kultury (producenci, wydawcy, twórcy) - z ograniczeniami wolności słowa i dostępu do treści rozpowszechnianych w sieci wydaje się dość odległy, ale tylko z pozoru. Zależności sugerowane w tytule niniejszego artykułu występują jednak faktycznie i można je wykazać poprzez analizę stopnia skorelowania wymienionych współczynników, przynoszących - w rezultacie stosowania prawnych 
środków mających ograniczać kradzieże intelektualne - także negatywne skutki w zakresie zarówno dość specyficznie rozumianej wolności słowa, jak i rzeczywistych ograniczeń swobód dostępu do treści rozpowszechnianych w sieci. Badania zaś wskazują, że internauci, zwłaszcza w wieku od 15 do 35 lat, bardzo często utożsamiają wolność słowa z wolnością dostępu do treści, traktując oba pojęcia wręcz jako synonimy.

W uproszczonym ujęciu piractwo zdaje się głównie poszerzać każdemu z użytkowników swobodny dostęp do bogactw Internetu. Ułatwia przekraczanie barier ekonomicznych i prawnych; umożliwia bezpłatne (bądź z niewielkimi opłatami) dotarcie do drogich i trudno dostępnych utworów audiowizualnych i multimedialnych. Mnożąc sfery nieskrępowanej wolności, serwisy pirackie pozwalają na penetrowanie i przyswajanie wielu atrakcyjnych dóbr kultury poza kontrolowaną dystrybucją, co użytkownicy czynnie wspierają, domagając się liberalizacji prawa autorskiego. „W moim przekonaniu jednak - pisze Ryszard Markiewicz - niektóre postulaty w ol no ś c i o we są nadmierne, a ich forma często nie jest stosowna"1. Zwłaszcza te wypowiedzi rozgrzeszające praktyki pirackie w imię demokratyzacji i wolnego dostępu do dóbr kultury.

Powszechne łamanie zasad dozwolonego użytku prywatnego i publicznego, a w tym internetowe piractwo, przyczyniają się zatem do wprowadzania kolejnych restrykcji prawnych niosących właśnie ograniczenia w dostępie, rozumianych przez młodych użytkowników jako swoista cenzura i zamach na wolność słowa. Tak postawiona hipoteza znajdzie odpowiednie rozwinięcie i uzasadnienie w niniejszym artykule. W racjonalnej ocenie przedstawionego wyżej zjawiska pomocna będzie analiza porównawcza wyników badań socjologicznych oraz prawno-ekonomicznych, zawartych w raportach renomowanych firm konsultingowych, a także analiza treści tak tradycyjnej prasy, jak i serwisów, portali internetowych.

Na wstępie należy zaznaczyć, że aspekt wolności (w tym wolności słowa) jest tu ujmowany w kontekście aksjologiczno-ontologicznym ze zrozumieniem, iż nie ma wolności absolutnej, że bywa i jest ograniczana, reglamentowana, a może być ujmowana jako wolność od ingerencji z zewnątrz, a jednocześnie wymaga „otwarcia się i aktywności wobec innych obiektów”2, co wskazuje na jej związek z równością i sprawiedliwością. Powyższe, dość szerokie rozumienie wolności słowa będzie się odnosić zarówno do przejawów działalności prasowej w tradycyjnym ujęciu, jak i do treści zamieszczanych w sieci w różnorodnych publikacjach o charakterze informacyjnym, publicystycznym czy artystycznym, rozpowszechnianych w Internecie, udostępnianych przez dostawców (w tym serwisy pirackie), pobieranych legalnie bądź nielegalnie i wykorzystywanych (w różnym zakresie) przez użytkowników sieci. Wolność pojawia się tu jako dobro (również dostępu do różnorodnych

${ }^{1}$ R. Markiewicz, Internet i prawo autorskie - wykaz problemów i propozycji ich rozwiązania, „Prace Własności Intelektualnej” 2013, z. 121, s. 18.

2 J. Sobczak, Ustawa prawo autorskie. Komentarz, Oficyna Prawnicza Muza SA, Warszawa 1999, s. 17. 
treści) gwarantowane przez Konstytucję RP oraz akty normatywne Unii Europejskiej. Ściślej rzecz ujmując, przedmiotem rozważań będzie głównie wolność dostępu do treści Internetu, a nie wolność słowa jako taka, jakkolwiek wybrane zagadnienia związane z jej naruszaniem zostaną także poruszone.

Niniejszej analizy autor dokonuje, opierając się na stanie prawnym z maja 2018 roku.

\section{Nielegalne pozyskiwanie}

Dla zobrazowania rozwijającej się od lat - zwłaszcza po 2010 roku - tendencji coraz szerszego korzystania $\mathrm{z}$ „bezpłatnych” treści udostępnianych w Internecie (ściągania plików z legalnych i nielegalnych źródeł oraz ich rozpowszechniania) przydatne będą wyniki badań zrealizowanych w 2011 roku przez Polskie Badania Internetu na ogólnopolskim panelu badawczym Ariadna, prowadzonym przez GG Network w ramach projektu GG Opinion Detector. Wykazały one między innymi, że około 40\% polskich internautów z grupy wiekowej 15-35 lat nigdy nie kupiło żadnych treści dostępnych w sieci (choć z nich korzystało). „Wśród pozostałych tylko co czwarty zapłacił za grę lub doładowanie do niej”3. Badania te nie dokumentowały, w jakim stopniu opłaty te były czynione na rzecz legalnych dystrybutorów czy też piratów. Dowodziły tylko (i to pośrednio), że więcej osób decydowało się na wnoszenie opłat za gry niż za dostęp do serwisów z serialami i filmami, jakkolwiek utwory te również pobierali.

Kolejne badania wykonane rok później (w lipcu 2012 roku) przez Megapanel PBI/Gemius oraz objęte sondażami przez cytowane już Polskie Badania Internetu (grupa 3105 internautów) potwierdzały, że 50\% polskich internautów „nigdy nie zapłaciło za treści czy usługi dostępne online, a 65\% uważało, iż w s z y s t k i e tre ści w Internecie powinny być dostępne za darmo"4. Zwłaszcza to przekonanie, podbudowane swoistym rozumieniem obywatelskiego prawa nieograniczonej dostępności do wszystkich treści rozpowszechnianych w sieci i ich jak najszerszej bezpłatnej eksploatacji, zaczęło dominować w przeróżnych argumentacjach użytkowników końcowych.

Przyrost w niespełna rok (o 10 punktów procentowych) użytkowników deklarujących bezpłatne pobieranie utworów od różnych dostarczycieli każe pytać o przyczyny owego wzrostu. Zastanowienie budzi zwłaszcza pojawiające się i mocno akcentowane oczekiwanie, że w Internecie „wszystko powinno być za darmo”.

${ }^{3} 40$ proc. polskich internautów nie płaci za e-treści, http://www.wirtualnemedia.pl/print/40-proc-polskich (dostęp: 2.03.2012).

${ }^{4}$ Połowa polskich internautów nie płaci za treści w sieci, http://www.wirtualnemedia.pl/artykul/ polowa-polskich-internautow-nie-placi-za-tresci-w-sieci (dostęp: 9.11.2012). 


\section{Przypadek ACTA}

Umowa Anti-Counterfeiting Trade Agreement z 2011 roku (zobowiązująca jej sygnatariuszy do walki z łamaniem prawa własności intelektualnej oraz handlem podrobionymi towarami), zawarta pomiędzy Australią, Kanadą, Japonią, Koreą Południową, Meksykiem, Maroko, Nową Zelandią, Singapurem, Szwajcarią i USA, do której miała dołączyć Unia Europejska, wymagała podpisania jej przez rządy poszczególnych państw unijnych, a następnie ratyfikowania przez krajowe parlamenty ${ }^{5}$. Polski rząd, podobnie jak rządy kilku innych państw UE, zapowiedział podpisanie umowy i wolę przystąpienie do ACTA. W całej Europie już w styczniu 2012 roku rozpoczęły się protesty ${ }^{6}$, wyrażane zarówno w sieci, jak i na ulicach wielu miast w postaci coraz gwałtowniejszych demonstracji; organizowano dni akcji "ACTA ad acta!", gromadzące tysiące młodych osób obawiających się cenzury online oraz ograniczeń ich praw do wolności. Natychmiast w zainicjowanej „walce o wolność" uaktywnili się politycy różnych ugrupowań, a także europejscy hakerzy z grupy Anonymous, Zielonych i Partii Piratów (Szwecja). Oświadczenia przeciwko ACTA wydawały liczne stowarzyszenia dziennikarskie, a sprzeciw wobec ACTA jednoczył opozycję nie tylko w Polsce, gdzie domagano się referendum, zaś lider jednej z głównych partii stwierdził, że wskutek ACTA „demokracja sprowadzana jest do fikcji, my takiego świata nie chcemy”. W stolicy Czech do ogólnoeuropejskich protestów wezwała Czeska Partia Piracka (jak najbardziej legalna), co wstrzymało tam proces ratyfikacji porozumienia ${ }^{7}$.

W takim skrótowym oglądzie owe protesty wydają się dziś nie do końca zrozumiałe. Rzecz w tym, że opinia publiczna nie była wprowadzona w meritum sprawy, media nie objaśniały istoty sporu, ekscytując się głównie protestami, demonstracjami; większość polskich obywateli nie znała ani treści umowy ACTA, ani jej rzeczywistych konsekwencji. Badania przeprowadzone w styczniu 2012 roku przez Millward Brown SMG/KRC i Centrum Cyfrowe Projekt: Polska wskazywały, że protesty mają charakter pokoleniowy. $43 \%$ badanych (w przedziale wiekowym 15-30 lat) wyrażało sprzeciw w obawie przed ograniczeniem ich wolności, a zwłaszcza wolnego dostępu do Internetu (jakkolwiek większość badanych nie znała treści oprotestowanej umowy), nie zgadzali się z niejawnym sposobem prowadzenia konsultacji przez rząd (30\%), a 12\% ankietowanych uważało, iż „protest przeciwko ACTA jest buntem piratów niezadowolonych z tego, że państwo ograniczy im możliwość ściągania plików z sieci”. Agencyjne doniesienia PAP z 31 stycznia 2012 roku o wynikach wspomnianych wyżej badań, zatytułowane „Młodzi Polacy

${ }^{5}$ Fragmenty niniejszego artykułu autor wykorzystał w publikacji na stronach newslettera nr 11/2018; zob. Z. Kosiorowski, Wolność słowa a prawo własności, czyli unijna nowelizacja prawa autorskiego, https://przegladdziennikarski.pl/wolnosc-slowa-a-prawo, 29.11.2018.

${ }^{6}$ Europa przeciw ACTA. Masowe protesty, www.newsweek.pl/swiat/europa-przeciwko-acta-masowe-protesty (dostęp: 9.05.2018).

7 Ostatecznie również Polska nie przystąpiła do ACTA. 
walczą o wolność, zwieńczono znamiennym zdaniem: „52\% badanych uznaje, że zachowanie darmowego dostępu do książek, filmów i muzyki jest elementem swobód obywatelskich i powinno być zachowane, nawet jeśli odbywa się z elementem naruszenia prawa autorskiego" ${ }^{\text {. }}$ W takim ujęciu za ważniejsze uznawano prawo do wolności dostępu (użytkowników) niż prawo do ochrony własności (autorów, producentów). Zasadnicze kwestie zawarte w ACTA, dotyczące ponoszonych przez twórców i przemysł kultury strat wskutek kradzieży intelektualnych, piractwa i nieuczciwej konkurencji oraz konieczności przeciwdziałania tym praktykom, media w zasadzie zagłuszyły ekscytującymi opinię publiczną relacjami z wieców i demonstracji, organizowanych - co prasa podkreślała w nagłówkach gazet - w imię „wolności słowa”.

Badania przeprowadzone w 2012 roku przez naukowców z Uniwersytetu Warszawskiego umożliwiły odpowiedź na pytanie, kto i dlaczego wyrażał sprzeciw wobec ACTA. „Facebookowe protesty przeciwko ACTA zgromadziły w zaledwie kilka dni łącznie kilkaset tysięcy osób (...), a profile »Nie dla ACTA w Polsce« popiera-

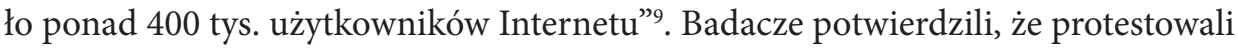
głównie młodzi użytkownicy - 78\% stanowiły osoby poniżej 24. roku życia. „Często protestują oni - czytamy w raporcie z badań - przeciwko idei, wyobrażeniu zagrożenia, a niekoniecznie przeciwko konkretnym zapisom"10. Konstatacja jednego z badaczy UW, dr. Jana Zająca, warta jest przytoczenia: „Chciałbym, żeby więcej Polaków zrozumiało szersze znaczenie przepisów ACTA, póki temat interesuje jeszcze media i opinię publiczną". Jego obawy, że media już jutro zapomną o ACTA, szukając świeżych newsów, szybko się potwierdziły.

Sprzeciw wobec ACTA jednoczył młode pokolenie, co badaczom, socjologom i psychologom społecznym dało podstawy do optymistycznych wniosków o pojawiającej się mobilizacji do działalności obywatelskiej, a także wzrostu społecznego i politycznego zaangażowania młodych użytkowników. Jednocześnie, jak się wydaje, rosło społeczne przyzwolenie na bezkarne zawłaszczanie cudzej własności w sieci zgodnie z rozpowszechnianym przez media i niektórych polityków przekonaniem, że zawartość Internetu winna być darmowa i dla każdego, a wolności dostępu i równej wolności słowa nie należy nikomu ograniczać, bo „godzi to w podstawy demokracji”.

Zasadniczy aspekt przedstawionych wyżej wydarzeń, istotę tamtego sporu oraz przyczynę burzliwych protestów młodych internautów trafnie ujęła Iwona Gleisner w przekonującej konkluzji: „Wolność dla przeciwników ACTA była nośnym hasłem, za którym kryła się obawa o sankcje za nielegalne ściąganie z Internetu treści objętych prawem autorskim, zaś troska zwolenników ACTA o ochronę praw właścicieli wartości intelektualnych była w istocie próbą zapewnienia sobie przez

${ }^{8}$ Zob. https://www.wprost.pl/290929/Mlodzi-Polacy-walcza (dostęp: 9.05.2018).

9 Badacze z UW sprawdzaja, kim sa protestujacy przeciwko ACTA, https://wpolityce.pl/ polityka/126316-badacze-z-uw, 31.01.2012 (dostęp: 11.05.2018).

10 Tamże. 
wielkie koncerny (głównie medialne) nowego skutecznego narzędzia powiększania zysków. W postawach obu stron zatem nie brakowało hipokryzji..."

\section{Oszustwa na polskim rynku usług internetowych}

Nasilenie popytu na atrakcyjne treści dostępne w sieci, a zwłaszcza te, za które użytkownicy nie musieli płacić, natrafiało po 2010 roku na coraz liczniejsze oferty internetowych oszustów. Pojawiały się one zarówno na rynku usług międzynarodowych (np. The Pirate Bay), jak i lokalnych w miarę rozwoju technologii i wprowadzenia szerokopasmowego dostępu, budząc coraz większe zainteresowanie. Ich aktywność wzrastała od końca lat 90 . ubiegłego stulecia, aż stała się znacząco groźnym pod względem ekonomicznym zjawiskiem przestępczego procederu, przynoszącego coraz większe straty gospodarcze. Porozumienie ACTA miało na celu przeciwdziałanie tym praktykom, jakkolwiek prawdą jest, że służyło głównie interesom dużych korporacji producentów, a także wprowadzało nadmiernie restrykcyjne ograniczenia w dozwolonym użytku prywatnym.

Pirackie efemerydy rodzące się na rodzimym rynku najczęściej były i są mocno inspirowane oraz osadzone w międzynarodowej sieci internetowych oszustów. W takiej nieprzypadkowej scenerii powstawał około 2010 roku Kinomaniak.tv, rozpowszechniający nielegalnie $\mathrm{w}$ internetowym serwisie utwory multimedialne, głównie filmy. Dwa lata później polski dystrybutor filmowy złożył na Kinomaniaka.tv doniesienie na policję, szacując swoje straty na blisko 26 milionów złotych. W prowadzonym dochodzeniu policja ustaliła, że serwis oferował nielegalne oglądanie filmów i seriali w formie online oraz ściąganie przez użytkowników innych utworów audiowizualnych. Oferta zawierała dwie możliwości: jednodniowy dostęp do bazy obejmującej około 100 tytułów za 2,5 złotego albo nieograniczony dostęp za odpłatnością 370 złotych. W serwisie Kinomaniak.tv można było oglądać filmy zagraniczne z polskimi napisami, często amerykańskie, bardzo krótko po ich premierze w USA, a przed oficjalnymi polskimi premierami. Serwis, skierowany głównie do polskich odbiorców (jego strona internetowa prowadzona była w języku polskim), szybko zyskał dużą popularność. Z jego usług korzystało 1,5 miliona użytkowników, co zaczęło się przekładać na znaczące zyski właścicieli serwisu, szacowane na 300 tysięcy złotych miesięcznie. Płacili zarówno internauci korzystający z pirackiego serwisu, jak i reklamujące się w nim firmy. Uzyskiwane środki z nielegalnej działalności pośrednicy finansowi Kinomaniaka.tv transferowali na konta zagraniczne, skąd po pewnym czasie przekazywano je do Polski. Olsztyńscy twórcy serwisu, chcąc uniknąć odpowiedzialności za ewidentne łamanie prawa, twierdzili, że Kinomaniak.tv jest własnością firm zarejestrowanych między innymi

${ }^{11}$ I. Gleisner, Problem wolności w Internecie, www.ujk.edu.pl/infotezy/ojs/index.php (dostęp: 21.04.2018). 
na Karaibach, a oni wykonują jedynie usługi techniczne. Prokurator wszczynający śledztwo w sprawie prania brudnych pieniędzy ${ }^{12}$ nie miał problemów $\mathrm{z}$ ustaleniem faktycznego miejsca prowadzenia nielegalnej działalności. Policja przeprowadziła przeszukania mieszkań, zabezpieczono znaczną ilość gotówki i sprzętu, a także karty płatnicze do zagranicznych kont bankowych. Prokurator skierował sprawę do sądu, a w styczniu 2014 roku sąd nakazał zamknięcie serwisu filmowego. Takie zakończenie oburzyło wielu internautów, którzy w komentarzach do artykułu zamieszczonego w Gazecie.pl pisali między innymi:

Totalną głupotą i absurdem jest wyliczanie strat na podstawie tego, ile osób obejrzało „piracki” film. Czyli wiadomo, że gdyby nie piraci, to osoby te poszłyby do kina lub kupiły oryginalne DVD?

26 mln - ładna kwota, tylko nieprawdziwa. Nie można przekładać 1 do 1 ilości użytkowników i pobrań na stratę dystrybutora ${ }^{13}$.

Po ogłoszeniu przez karaibską spółkę z Olsztyna zakończenia działalności w Internecie pojawił się nowy twór - C kinoman.tv, działający na tej samej zasadzie co Kinomaniak, a także inne bardziej lub mniej legalne propozycje, jak serwis Kinoplex czy eKino.TV ${ }^{14}$.

Przypadek Kinomaniaka jest jednym z wielu przykładów działalności pirackiej na polskim rynku usług internetowych, wspieranej całkiem świadomie przez niektórych internautów tak ceniących wolność dostępu równą, w ich przekonaniu, wolności słowa.

Późniejsze badania CBOS (z lat 2014-2016) potwierdzały utrzymywanie się wspomnianych tendencji; przy rosnącej liczbie internautów coraz mniej użytkowników Internetu (8\%) korzystało „z usług lub treści dostępnych za opłatą”, zaś „pobieranie z sieci darmowych programów, muzyki i filmów deklarowała ponad jedna czwarta korzystających z Internetu (28\%), czyli 18\% ogółu badanych. Częściej robili to młodsi (54\%) niż starsi internauci”" ${ }^{15}$. Co trzeba jeszcze raz podkreślić, z powyższych badań nie wynikało wprost, w jakim stopniu pobieranie plików dokonywało się ze źródeł legalnych, a w jakim z sieci pirackich. Jednak internauci korzystający w latach 2014-2016 z wyszukiwarek (głównie z Google) przyznawali, że po wpisaniu tytułu poszukiwanego filmu otrzymują najpierw informacje ze stron

${ }^{12}$ Był to bodaj najprostszy i najbardziej skuteczny wówczas sposób walki z piractwem internetowym wobec braków odpowiednich przepisów prawa polskiego, przymierzającego się do implementacji dyrektywy unijnej.

${ }_{13}$ Zob. http://wiadomości.gazeta.pl/wiadomości/1,114871,15641489,Jest_(dostęp: 7.02.2018).

${ }_{14}$ Zob. www.se.pl/wiadomosci/dziejesie/co-zamiast-kinomaniak-zobacz (dostęp: 7.02.2018).

${ }_{15}$ Korzystanie $z$ internetu, CBOS, Komunikat z badań nr 92/2016, http://www.cbos.pl/SPISKOM. POL/2016/K_092_16.PDF (dostęp: 26.04.2018). 
zawierających nielegalne treści, co nie mogło pozostać bez wpływu na ich ewentualne wybory ${ }^{16}$.

\section{Nielegalne pozyskiwanie utworów multimedialnych}

Popularność ściągania plików z nielegalnego kina online VOD, udostępnianie przez pirackie serwisy fragmentów przestrzeni dyskowej serwera wirtualnego do przechowywania i udostępniania plików, coraz częstsze korzystanie przez użytkowników z odtwarzania strumieniowego (portale bazujące na tzw. user-generated content) stało się obecnie podstawą ułatwiającą kradzieże własności intelektualnej.

Jedną z często występujących form piractwa medialnego jest nielegalne pozyskiwanie utworów multimedialnych, w tym gier komputerowych, ich kopiowanie i niedozwolone rozpowszechnianie. Z sondaży i badań ankietowych przeprowadzonych w 2017 roku przez studentkę Zachodniopomorskiej Szkoły Biznesu w Szczecinie wynikało, że większość (około 75\%) respondentów ${ }^{17}$ korzystała z gier pozyskanych z nielegalnego źródła, a tylko 7\% graczy deklarowało, że nigdy z takiego źródła nie korzystało. Symptomatyczne było nastawienie graczy do nielegalnego pobierania gier z pirackich stron internetowych (czyli de facto kradzieży), bo choć 49\% przyznawało, że jest to czyn nieetyczny, to jednocześnie uważało, że takie postępowanie nie powinno być karane, a blisko 20\% w owej kradzieży nie widziało nic złego. Otrzymane przez studentkę wyniki wskazywały, że blisko 60\% graczy miało świadomość łamania prawa, a mimo to sprzeciwiało się zakazom pobierania treści z nielegalnych, pirackich serwisów. Badania ponadto wykazały, że brak prostej zależności między zasobnością graczy i wysokością cen gier a częstotliwością kradzieży występujących w grupach zróżnicowanych pod względem dochodu. Zarówno ubożsi, jak i ci zasobniejsi ujawniali ten sam poziom lekkomyślnego zainteresowania nielegalnym pozyskiwaniem gier w myśl założenia, że „gdyby gra nie była dostępna w wersji pirackiej, nie zostałaby i tak kupiona na legalnym rynku, a ewentualne zaostrzenie kar za piractwo internetowe nie zmniejszy jego poziomu”. Wyniki tych badań potwierdzały uzasadnione przypuszczenie o coraz szerszym sięganiu przez internautów po nielegalne źródła dostępu oraz notorycznym korzystaniu z usług pirackich serwisów.

W związku z powyższym producenci telewizyjni (np. Canal+) i ich internetowe platformy legalnie udostępniające filmy i seriale powołują obecnie wyspecjalizowane komórki zajmujące się walką z piractwem. I tak na przykład platforma nc+ wykryła „ponad 200 tysięcy różnych naruszeń praw autorskich do odcinków

16 Zob. http://www.antyweb.pl/piractwo-w-sieci-wyszukiwarki/ (dostęp: 28.09.2017).

${ }_{17}$ M. Krowiak, Rozwój rynku gier komputerowych w Polsce i jego ograniczenia powodowane nielegalnym pozyskiwaniem gier, praca magisterska, promotor Z. Kosiorowski, Archiwum cyfrowe ZPSB, Szczecin 2017. 
pierwszego sezonu Belfra. Usunęła zaś dostęp do 150 tysięcy źródeł pirackich kopii serialu - w tym 80 tysięcy linków z Google’a oraz 70 tysięcy plików serwisu Chomikuj.pl"18.

Hakerzy - co przekazała portalowi Wirtualnemedia.pl Paulina Smaszcz-Kurzajewska z Canal+ - znajdują nowe sposoby łamania blokad dostępu. „W przypadku udostępniania nielegalnych kopii Belfra zmieniają nazwę serialu na angielskojęzyczną Teacher, zamieszczają statyczny obraz i dodają adres URL w opisie pirackiego materiału wideo"19. Główny ciężar walki z piractwem internetowym przyjmują więc na siebie producenci seriali i filmów oraz gier komputerowych, oczekując jednak od ustawodawców wsparcia poprzez wprowadzanie jaśniejszych przepisów prawa, ułatwiających skuteczniejsze ściganie oszustów w sieci. Owa dążność do wprowadzenia bardziej restrykcyjnych przepisów ograniczających dozwolony użytek prywatny jest wspierana i artykułowana przez firmy konsultingowe realizujące wiele badań ilustrujących ekonomiczno-gospodarcze skutki piractwa. Użytkownicy zaś milcząco wspierają piratów, surfując po sieci i wyszukując atrakcyjne oraz darmowe treści; kradną coraz częściej i coraz więcej, licząc na bezkarność w imię wolności dostępu, bowiem „dwie trzecie Polaków uważa, że korzystanie na własny użytek $\mathrm{z}$ udostępnionych w sieci dóbr kultury nie może być nazywane kradzieżą (...) i nie powinno być moralnie, ale i prawnie piętnowane" ${ }^{20}$.

\section{Ekonomiczne skutki piractwa}

Z dostępnych badań wynika ${ }^{21}$, że w Polsce podobnie jak w innych państwach UE, wskutek łatwości i częstości sięgania po nielegalne źródła w Internecie, najbardziej poszkodowane są rynki kreatywne: rynek wideo, rynek transmisji online, rynek muzyki, książki, audiobooków, a także prasy. Pierwotnie dość prymitywne sposoby korzystania z usług internetowych zastąpiono obecnie efektywniejszymi modelami nielegalnego dostępu (trudniejszego do kontroli), jak streaming na żywo, streaming na żądanie, hosting plików, wymiana w sieci BitTorrent oraz linkowanie.

Centrum Cyfrowe Projekt: Polska podało jesienią 2017 roku, że ponad 90\% rodaków za oczywisty uznaje swobodny (wolny) dostęp do Internetu jako niezbywalny element ich codziennego życia. Jednocześnie aż dwie trzecie użytkowników „uważa, że korzystanie na własny użytek z udostępnionych w sieci dóbr kultury nie może być nazwane kradzieżą ${ }^{22}$. Z badań CCP wynikało, że mamy w Polsce oko-

${ }^{18} \mathrm{Nc}+$ zlikwidowało 150 tys. pirackich źródeł „Belfra”, 70 tys. z samego Chomikuj.pl, http://www. wirtualnemedia.pl/arykul/piracka-wersja-serialu (dostęp: 27.09.2017).

19 Tamże.

20 Zob. www.pi.gov.pl/PART/chapter_86197.asp? (dostęp: 10.05.2018).

${ }^{21}$ Raport Deloitte Legal na zlecenie Fundacji Kreatywna Polska, Warszawa 2017.

${ }^{22}$ M. Antonowicz, Piractwo w internecie - straty dla kultury, „Wiadomości ZAiKS” 2017, nr 17, s. 10 . 
ło 23 milionów użytkowników Internetu (około 78\% Polaków w grupie wiekowej od 15 do 75 lat), z czego blisko 12 milionów korzysta z nielegalnych źródeł w sieci (głównie z pirackich plików wideo i audiobooków) ${ }^{23}$.

W raporcie Deloitte Legal, która analizowała w 2017 roku problem piractwa internetowego w Polsce (za rok 2016), czytamy, że około 15\% użytkowników korzystało wyłącznie z nielegalnych źródeł - z serwisów oferujących nielegalny dostęp, płacąc za to de facto „paserom” średnio od 11 do 23 złotych miesięcznie (od osoby), czyli około 745 milionów złotych. Szacując skutki ekonomiczne tego procederu, badacze Deloitte wykazali, że piractwo treści w Internecie „generuje straty dla polskiej gospodarki na poziomie 3 miliardów rocznie, co stanowi około $30 \%$ wartości rynku eksportu dóbr kultury z Polski do państw trzecich w 2016 roku; dla Skarbu Państwa strata wynosi około 836 milionów złotych"24. Analitycy wspomnianej firmy prognozowali jednocześnie, że: „[w] latach 2017-2024 średnie tempo wzrostu piractwa sięgnie 3,3\% i będzie zdecydowanie wyższe niż średnie tempo wzrostu PKB w tym okresie"25, co może budzić wątpliwości. Nie da się tu uniknąć porównań zastosowanego przez Deloitte sposobu szacowania strat z metodą wykorzystaną znacznie wcześniej przez znaną francuską firmę konsultingową badającą rynek UE w kontekście skutków piractwa internetowego.

W roku 2010 biegli z firmy Tera Consultants ${ }^{26} \mathrm{z}$ Paryża wyliczyli, że jeśli UE nie zaostrzy przypisów w zakresie ochrony własności intelektualnej, to do roku 2015 w 27 państwach UE z powodu postępującego piractwa pracę straci 1,2 miliona ludzi zatrudnionych w branżach związanych z twórcami - w sektorach muzycznym i wydawnictw książkowych, zaś straty w handlu detalicznym tych branż sięgną $240 \mathrm{mi}-$ liardów euro. Tak postawiony problem spowodował pilne zajęcie się nim przez Komisję Europejską i Parlament Europejski, w efekcie czego wprowadzono (z wielkimi oporami i protestami użytkowników, jak na przykład przy ACTA) kolejne dyrektywy mające ograniczyć piractwo. Niestety, po roku 2015 nikt już nie sprawdzał, czy przewidywania Tera Consultants uzyskały potwierdzenie. Gdyby ich szacunki nie były przesadzone, mielibyśmy dziś w UE miliony bezrobotnych twórców, wydawców, producentów, a cała branża muzyczna i filmowo-telewizyjna byłaby w fazie regresu, a tak nie jest.

Zastosowaną przez Tera Consultants metodę szacowania strat powieliła w rok później australijska firma Sphere Analysis, która w 2011 roku, idąc śladem analityków francuskich i stosując tę samą metodologię badań, ogłosiła, że australijski

${ }^{23}$ Według najnowszych badań Gemius PBI liczba internautów w Polsce w styczniu 2018 roku wyniosła ogółem 28 milionów; zob. www.pbi.org.pl/badania-gemius-pbi/polski-internet-styczen-2018 (dostęp: 3.03.2018).

${ }^{24}$ M. Antonowicz, dz. cyt., s. 10.

25 Tamże.

${ }^{26}$ TC świadczy usługi doradcze dla ponad 50 krajów, uważana jest za jedną z lepszych firm konsultingowych na świecie, specjalizuje się między innymi w ocenie poziomu rozwoju przemysłów kreatywnych, stosując metodologię pomiaru stanu badanych przemysłów w odniesieniu do ich udziału w PKB. Więcej: http://www.teraconsultants.fr/en/newsletter (dostęp: 4.04.2018). 
przemysł muzyczno-rozrywkowy traci rocznie 900 milionów dolarów z powodu pirackiej wymiany plików w sieci. Australijski prokurator generalny, powołując się na ów raport, wszczął stosowne postępowanie, a wtedy prasa na antypodach rozpoczęła poszukiwania zarówno australijskiego raportu (który jakiś czas był utajniony), jak i tego wcześniejszego, z Paryża. Okazało się, że Australijczycy bezkrytycznie przejęli metodologię Francuzów i bazowali na „zastosowaniu tego studium do australijskiego kontekstu, aby oszacować bazę dla strat w sprzedaży detalicznej, utraconych miejsc pracy i utraconych przychodów z podatków" ${ }^{27}$. Faktu, że rosnąca liczba internautów i coraz szybsze, dostępniejsze łącza wpływają potencjalnie na rosnącą skalę piractwa, a tym samym na poziom strat ponoszonych przez okradane przez piractwo gospodarki poszczególnych krajów, nie daje się zakwestionować. Wątpliwości budził jednak końcowy sposób wyliczenia owych strat globalnych w obu raportach, jak i wyraźna tendencja straszenia nimi. Była ona wyraźna i w raporcie z roku 2010 (Tera Consultants), i w tym z roku 2011 (Sphere Analysis), ale też - niestety - w dotyczącym polskiego rynku raporcie Deloitte z roku $2017^{28}$.

\section{Zagrożenia dla wolności słowa}

Przedstawiona w zarysie tzw. walka o „wolność w sieci i wolny Internet” z gruntu dotyczyła różnorakich form domagania się jak najszerszego i bezpłatnego dostępu do treści w sieci. Z kolei wprowadzane w tym zakresie restrykcyjne przepisy (np. ACTA czy kolejne dyrektywy UE, poprzedzane katastroficznymi raportami o skutkach ekonomicznych piractwa) niosły także ograniczenia godzące pośrednio i bezpośrednio w dość szeroko rozumianą wolność słowa, co wielu użytkowników mogło kojarzyć z zagrożeniem cenzurą. Media, rezygnując (na ogół) ze swych edukacyjnych powinności, karmiły odbiorców coraz częściej kreowanymi newsami, podgrzewały atmosferę owej „walki o wolność słowa w sieci”29, odstępując jednocześnie od rzeczowego przedstawiania powstałego konfliktu interesów, bo ten był za trudny do objaśnienia i nie niósł odpowiedniej porcji emocji, nakręcającej tak cenioną „klikalność”. Nie zadbano o prawidłowe zdefiniowanie istotnych pojęć, takich jak wolność słowa (w Internecie) czy wolność dostępu do treści w sieci, oraz ich zasadnicze rozróżnienie. Wolność na transparentach skupiała uwagę,

27 M. Maj, Tajny antypiracki raport odnaleziony, di.com.pl/tajny-antypiracki-raport-odnaleziony-36669 (dostęp: 8.02.2018).

${ }^{28} \mathrm{~W}$ raportach przyjęło między innymi błędne założenie, że istnieje całkowita, dająca się precyzyjnie oznaczyć korelacja między wzrostem ruchu w sieci, piractwem i stratami przemysłu kultury, oparta na wątpliwym szacunku, że na przykład liczba nielegalnych pobrań równa się określonej stałej stracie, czego analitycy w żaden sposób nie udowodnili.

29 Wybiórcza kwerenda zawartości gazet codziennych, kilku tygodników, a zwłaszcza stała analiza zawartości wielu serwisów społecznościowych i platform internetowych w latach 2010-2018 dają podstawy do przyjęcia tak sformułowanego wniosku. 
przyciągała miliony sympatyków i sprzedawała się lepiej niż ekonomiczne konsekwencje źle rozumianej wolności zawarte w cyfrach o skutkach kradzieży w sieci.

Niejako na uboczu pozostawała prawda, że największym zagrożeniem dla wolności słowa w Internecie jest anonimowość jego użytkowników. Z czasem ofensywa źle pojmowanej wolności słowa przyniosła nagminne obrażanie, perfidne znieważanie, naruszanie dóbr osobistych, a także coraz niższy poziom publicznych debat nie tylko w serwisach społecznościowych, co przyczyniało się do wprowadzania aktywniejszych form ochrony praw osób pokrzywdzonych. Jednocześnie ten sam Internet, kojarzony z wolnością wypowiedzi, staje się coraz częściej narzędziem inwigilacji i swoistego nadzoru nad obywatelami.

W maju 2018 roku SDP, Centrum Monitoringu Wolności Prasy i Instytut na rzecz Kultury Prawnej Ordo Iuris zorganizowały debatę poświęconą wolności słowa w Internecie $e^{30}$. Zadano pytanie, czy w Internecie istnieje cenzura, zauważono bowiem przypadki cenzurowania wypowiedzi internautów przez administratorów serwisów społecznościowych. Prawnik Ordo Iuris podał dane, że „na całym świecie na Facebooku kasowanych jest tygodniowo blisko 66 tysięcy postów”31. Domagano się więc czytelnej procedury odwoławczej dla użytkownika, któremu serwis zablokował profil lub konkretną opublikowaną treść. „Dostęp do informacji i ich swobodny przepływ jest dla nas de facto warunkiem istnienia” - uzasadniał swe postulaty przedstawiciel Google, dodając, że „obszar wolności jest sukcesywnie grodzony, ograniczany, w jakiś sposób regulowany na różnych polach, na przykład praw autorskich”32. Przedstawiciel SDP skonstatował, że oto „mamy więc problem z wolnością w Internecie”, co zabrzmiało bardziej wyraziście, niż gdyby odniósł się do zagrożeń rzetelności i obiektywizmu tzw. mediów publicznych. Konteksty owej debaty, jak najbardziej potrzebnej, mieszczą się w nurcie bulwersującej „afery postfacebookowej" i jej próby zdefiniowania jako przejawu zagrożeń dla prywatności użytkowników, a jednocześnie skutkującej całym szeregiem wprowadzanych ograniczeń dla internautów. Ograniczeń dyskutowanych już znacznie wcześniej, bo jeszcze przed wyborami prezydenckimi w USA i tegorocznymi zeznaniami Marka Zuckerberga przed Komisją Senatu, gdzie przyznał on, że utracił kontrolę nad stworzonym przez siebie światem. Już w 2016 roku Komisja Europejska wprowadziła zmiany do prawa autorskiego, w których zobowiązywano operatorów serwisów online działających jako platformy zamieszczające materiały muzyczne i filmowe do bieżącego monitorowania tego, co wrzucają (np. do YouTube) jego użytkownicy. W regulacjach tych chodziło o „zwiększenie odpowiedzialności firm internetowych za bezprawnie wrzucane treści" ${ }^{33}$. Jednocześnie KE zapowiadała kolejne regulacje zobowiązujące portale do uprzedniego filtrowania publikowanych na nich

${ }^{30}$ Debata zorganizowana 8 maja 2018 roku w siedzibie SDP przy ul. Foksal w Warszawie.

${ }_{31}$ Zob. http://www.wirtualnemedia.pl/artykul/cenzura-w-internecie (dostęp: 9.05.2018).

32 Tamże.

${ }^{33}$ E. Świętochowska, Walka z piratami zagraża cenzurą w sieci, „Dziennik Gazeta Prawna”, 20.09.2016, s. B6. 
materiałów, co część zajmujących się tym problemem publicystów uznała za formę cenzury.

Kolejnym krokiem, nieco wyprzedzającym kryzys związany z naruszaniem zasad prywatności oraz dyskusje na temat afery Cambridge Analytica, była unijna regulacja szerokiego obszaru wolności Internetu (RODO) poprzez przepisy mające lepiej chronić prywatność jego użytkowników. Równolegle w kilku krajach zaczęły się pojawiać próby inicjowania różnych form państwowej kontroli w Internecie, na przykład kontrowersyjne rozwiązania wprowadzone w Chinach, mające służyć tworzeniu systemu tzw. zaufania społecznego ${ }^{34}$, a polegające na „podglądaniu” użytkowników i pozyskiwaniu danych będących podstawą do profilowania ich oraz oceny w różnorakich kontekstach aktywności również poza siecią. Bez wątpienia mamy tu do czynienia z przykładem wyrafinowanej formy śledzenia i infiltrowania obywateli przez totalitarne rządy.

W okresie kampanii wyborczej Władimira Putina Federalna Służba do spraw Nadzoru w Sferze Łączności, Technologii Informacyjnych i Komunikacji Masowej podjęła próby zablokowania ponad 16 milionów adresów IP Rosjan korzystających z messengera Telegram, aby odciąć ich od tych form komunikacji, które najtrudniej było kontrolować ${ }^{35}$. Federalna Służba Bezpieczeństwa domagała się wcześniej wydania jej kluczy do szyfrowania komunikatów przesyłanych przy użyciu messengera, co uznano za wprowadzenie cenzury. Ponieważ działania służb wobec Telegrama okazały się mało skuteczne, podjęto próby zmuszenia Google’a i Amazona do usunięcia Telegrama i zagrożono Facebookowi blokadą. Skutki tych ingerencji zaczęły odczuwać rosyjskie i zagraniczne firmy, nie tylko prywatne osoby. Walka z prywatnością i swobodą wypowiedzi stała się obecnie w Rosji przykładem ograniczania wolności słowa oraz próbą cenzurowania niewygodnych dla rządu treści ${ }^{36}$. Zdaniem obserwatorów rynku internetowego „Rosja zdelegalizowała anonimowość (...). Duma przyjęła regulację umożliwiającą zablokowanie dowolnego serwisu pod pretekstem zwalczania terroryzmu" ${ }^{37}$.

W Polsce, w Ministerstwie Cyfryzacji, wiosną 2018 roku zainicjowano prace nad powołaniem zespołu do spraw mediów społecznościowych. Inicjatywa ta nie budziłaby niepokoju, gdyby nie uzasadnienie posłanki postulującej utworzenie takiego zespołu, „między innymi w związku z sygnałami, jakoby media społecznościowe, w tym i Facebook, dyskryminowały osoby o poglądach prawicowych" 38 . Wymiana poglądów na powyższy temat z 18 kwietnia 2018 roku pomiędzy internautami

34 E. Bendyk, Nowa republika sieci, „Polityka” 2018, nr 20, s. 71.

35 W. Radziwinowicz, Rosja z maczuga na internet, „Gazeta Wyborcza”, 19.04.2018, s. 8.

36 R. Kędzierski, Kreml staje na głowie, by zablokować ten popularny komunikator. Powód? Zapewnia Rosjanom prywatność, http://next.gazeta.pl/next/7,151243,23354575,kreml-staje-na-glowie (dostęp: 6.05.2018).

37 Tamże.

38 T. Mileszko, Polski rząd chce powołać zespół ds. mediów społecznościowych, www.komputerswiat.pl/nowosci/internet/2018/16/polski-rzad-powola (dostęp: 20.04.2018). 
z udziałem pani poseł oraz ministra cyfryzacji ${ }^{39}$ jest bardzo znamienna i zmusza do uważnego śledzenia postępów ministerstwa w tworzeniu nowych regulacji, które mogą być zarówno korzystne dla zachowania prywatności użytkowników i poszanowania ich dóbr osobistych, jak i nieść zagrożenia dla wolności słowa w Internecie.

\section{Konkluzje}

Dobiega końca ${ }^{40}$ trwająca od ponad roku dyskusja nad Pakietem Praw Autorskich Komisji Europejskiej, stanowiącym podstawę reformy unijnego prawa autorskiego, a będącym ważnym elementem tzw. Strategii Jednolitego Rynku Cyfrowego. Celem jest, jak podkreśla w swym dokumencie KE, stworzenie „bardziej zharmonizowanego systemu praw autorskich, który będzie zachęcał do tworzenia oraz inwestowania, a jednocześnie pozwoli na przekazywanie i konsumowanie treści ponad granicami, współtworząc naszą bogatą różnorodność kulturową"41. Spory wokół tego, jak wcielić w życie owo hasło, wzbudzają wiele kontrowersji wśród podmiotów zainteresowanych wprowadzeniem najkorzystniejszych dla siebie rozwiązań legislacyjnych. Mamy bowiem różne strony uczestniczące w tych trwających od lat manewrach, ale różnice między antagonistami nie dotyczą w zasadzie kwestii zdawałoby się oczywistych: co jest lepsze dla rozwoju nauki i kultury oraz wolności słowa? Czy ograniczanie swobodnego dostępu do treści zamieszczanych w Internecie, czy też nieskrępowane prawem swobodne korzystanie z owych treści (utworów)? W grze o zachowanie prymatu na rynku internetowym, kumulującym w różnorakich transakcjach setki miliardów dolarów, uczestniczą grupy interesów z kręgu przemysłu kultury, reprezentanci producentów filmowych, muzycznych i telewizyjnych.

Pytanie o miejsce w tym sporze dla indywidualnych użytkowników Internetu, którzy przecież zasadniczo napędzają ów imperialno-internetowy interes, pojawia się jakby okazjonalnie. Rzecz w tym, że jednocześnie coraz większa liczba internautów pobiera świadomie i nieświadomie z nielegalnych źródeł filmy, seriale, gry komputerowe oraz inne kradzione pliki audio/wideo, wspierając przemysł piracki, czym przyczynia się do rosnących strat producentów, wykonawców i twórców. Szacuje się, że strony zawierające treści naruszające prawa autorskie odwiedzane są sumarycznie każdego roku blisko 60 miliardów razy. Być może również dlatego domaganie się przez młodych użytkowników wolności dostępu jako wyrazu

39 Zainteresowanych wymianą poglądów na temat wspomnianej inicjatywy autor odsyła do: https://twitter.com/ZagorskiMarek/status/9866177709043009761?ref_src= (dostęp: 20.04.2018).

40 Stan prawny na maj/czerwiec 2018 roku.

${ }^{41}$ A. Misiewicz, Europejska reforma prawa autorskiego - stan gry po roku, „Wiadomości ZAiKS”, grudzień 2017, s. 15. 
poszanowania wolności słowa (choćby i tak opacznie rozumianej i błędnie definiowanej, jak to wykazano w niniejszym artykule) bywa marginalizowane i budzi jedynie wzruszenie ramion; gra toczy się bowiem o inną stawkę.

„Walka o wolność słowa” pojawiająca się w nagłówkach artykułów wielu dzienników i czasopism oraz na stronach serwisów internetowych, nadużywana w doniesieniach o sprzeciwie internautów wobec jakichkolwiek ograniczeń w korzystaniu z prywatnego dozwolonego użytku oraz używanie tego pojęcia jako zastępczego wobec na przykład hasła „batalia z ograniczeniami w dostępie do treści” przyczyniły się w dużym stopniu do błędnego pojmowania kanonu wolności słowa. Potwierdzają to cytowane badania i analizy treści zawartości gazet i czasopism, zwłaszcza tytułów relacji i sprawozdań. Notoryczny brak merytorycznego odnoszenia się większości dziennikarzy do przyczyn i skutków piractwa internetowego zamęt ów jeszcze pogłębia. Korzystanie z „cudzego” i postępujące okradanie twórców i producentów nie znalazło niestety właściwych, oceniających i wprowadzających prawny ład komentarzy.

Ryzykowne, zdawałoby się, sugerowanie związków i korelacji między piractwem internetowym a ograniczeniami dostępu do treści oraz wolności słowa znajduje wszakże uzasadnienie w przedstawionych wyżej faktach i interpretacjach. Podobnie jak hipoteza, że podejmowane prawne środki walki z piractwem, poniekąd prowokowane przez nieuczciwych użytkowników, ograniczają w rezultacie wszystkim internautom dostęp do rozpowszechnianych treści. Natomiast ograniczenia w zakresie wolności słowa w Internecie stają się najczęściej pochodną stosowania przez poszczególne państwa szeregu środków tzw. kontroli prywatności i zapobiegania naruszeniom dóbr osobistych. Kwestie te wymagają jednak odrębnego potraktowania i nie były głównym przedmiotem tego artykułu.

\section{Bibliografia}

40 proc. polskich internautów nie płaci za e-treści, http://www.wirtualnemedia.pl/print/40-proc-polskich (dostęp: 2.03.2012).

Antonowicz M., Piractwo w internecie - straty dla kultury, „Wiadomości ZAiKS” 2017, nr 17, s. 10.

Badacze z UW sprawdzaja, kim sa protestujący przeciwko ACTA, 31.01.2012, https://wpolityce. pl/polityka/126316-badacze-z-uw (dostęp: 11.05.2018).

Bendyk E., Nowa republika sieci, „Polityka” 2018, nr 20, s. 71.

Europa przeciw ACTA. Masowe protesty, www.newsweek.pl/swiat/europa-przeciwko-acta-masowe-protesty (dostęp: 9.05.2018).

Gleisner I., Problem wolności w Internecie, www.ujk.edu.pl/infotezy/ojs/index.php (dostęp: 21.04.2018).

http://wiadomości.gazeta.pl/wiadomości/1,114871,15641489,Jest_(dostęp: 7.02.2018).

http://www.antyweb.pl/piractwo-w-sieci-wyszukiwarki/ (dostęp: 28.09.2017).

http://www.teraconsultants.fr/en/newsletter (dostęp: 4.04.2018).

http://www.wirtualnemedia.pl/artykul/cenzura-w-internecie (dostęp: 9.05.2018). 
https://www.wprost.pl/290929/Mlodzi-Polacy-walcza (dostęp: 9.05.2018).

Kędzierski R., Kreml staje na głowie, by zablokować ten popularny komunikator. Powód? Zapewnia Rosjanom prywatność, http://next.gazeta.pl/next/7,151243,23354575,kreml-staje-na-glowie (dostęp: 6.05.2018).

Korzystanie z internetu, CBOS, Komunikat z badań nr 92/2016, http://www.cbos.pl/SPISKOM. POL/2016/K_092_16.PDF (dostęp: 26.04.2018).

Krowiak M., Rozwój rynku gier komputerowych w Polsce i jego ograniczenia powodowane nielegalnym pozyskiwaniem gier, praca magisterska, promotor Z. Kosiorowski, Archiwum cyfrowe ZPSB, Szczecin 2017.

Maj M., Tajny antypiracki raport odnaleziony, di.com.pl/tajny-antypiracki-raport-odnaleziony-36669 (dostęp: 8.02.2018).

Markiewicz R., Internet $i$ prawo autorskie - wykaz problemów i propozycji ich rozwiąania, „Prace Własności Intelektualnej” 2013, z. 121, s. 18.

Mileszko T., Polski rząd chce powołać zespół ds. mediów społecznościowych, www.komputerswiat.pl/nowosci/internet/2018/16/polski-rzad-powola (dostęp: 20.04.2018).

Misiewicz A., Europejska reforma prawa autorskiego - stan gry po roku, „Wiadomości ZAiKS”, grudzień 2017, s. 15.

Nc+ zlikwidowało 150 tys. pirackich źródet „Belfra”, 70 tys. z samego Chomikuj.pl, http://www. wirtualnemedia.pl/arykul/piracka-wersja-serialu (dostęp: 27.09.2017).

Połowa polskich internautów nie płaci za treści w sieci, http://www.wirtualnemedia.pl/artykul/ polowa-polskich-internautow-nie-placi-za-tresci-w-sieci (dostęp: 9.11.2012).

Radziwinowicz W., Rosja z maczuga na internet, „Gazeta Wyborcza”, 19.04.2018, s. 8.

Raport Deloitte Legal na zlecenie Fundacji Kreatywna Polska, FKP, Warszawa 2017.

Sobczak J., Ustawa prawo autorskie. Komentarz, Oficyna Prawnicza Muza SA, Warszawa 1999. Świętochowska E., Walka z piratami zagraża cenzura $w$ sieci, „Dziennik Gazeta Prawna”, 20.09.2016, s. B6.

www.pbi.org.pl/badania-gemius-pbi/polski-internet-styczen-2018 (dostęp: 3.03.2018).

www.pi.gov.pl/PART/chapter_86197.asp? (dostęp: 10.05.2018).

www.se.pl/wiadomosci/dziejesie/co-zamiast-kinomaniak-zobacz (dostęp: 7.02.2018). 